\title{
Phytodepuration of the effluents in a closed system of fish production
}

\author{
Fitodepuração de efluentes em sistema fechado de produção de peixes
}

\author{
CANI, Antônio Carlos Pinheiro ; AZEVEDO, Rafael Vieira de ${ }^{2}$; PEREIRA, Rogério \\ Novais ${ }^{3}$; OLIVEIRA, Mônica Alves de ${ }^{3}$; CHAVES, Modesto Antônio ${ }^{3}$; BRAGA, Luís \\ Gustavo Tavares $^{4 *}$
}

\footnotetext{
${ }^{1}$ Instituto Federal de Educação, Ciência e Tecnologia do Norte de Minas Gerais, Salinas, Minas Gerais, Brasil.

${ }^{2}$ Universidade Estadual do Norte Fluminense Darcy Ribeiro, Programa de Pós-graduação em Ciência Animal, Campos dos Goytacazes, Rio de Janeiro, Brasil.

${ }^{3}$ Universidade Estadual do Sudoeste da Bahia, Itapetinga, Bahia, Brasil.

${ }^{4}$ Universidade Estadual de Santa Cruz, Departamento de Ciências Agrárias e Ambientais, Ilhéus, BA, Brasil.

*Endereço para correspondência: lgtbraga@gmail.com
}

\section{SUMMARY}

It was evaluated the feasibility of growing lettuce intercropped with Nile tilapia farming in a hydroponic system and the efficiency upon the improvement of the quality of the effluent. The experimental structure was composed of one module for fish production and other for plant production in the hydroponic system. It was used production technique NFT (Nutrient Film Technique), and the nutrient solution used was the effluent of fish farming. It was used a randomized block experimental design with four treatments and three replications, considering each repetition an 8-day cycle in hydroponics. The treatments were: 20;40, 60 and 80 plants for the first, second, third and fourth treatments, respectively. Electrical conductivity, $\mathrm{pH}$, temperature and dissolved oxygen did not change $(\mathrm{P}>0.05)$ in relation to the input effluent and they were not affected $(\mathrm{P}>0.05)$ by the number of plants. We observed a linear effect of number of plants on the parameters orthophosphate and nitrite, ie the higher the number the greater the removal of plants for these parameters in the water.-The percentage of nitrogen in leaves and roots of lettuce was not influenced by the number of plants. There was a linear effect of the number of plants on the accumulation in lettuce leaves parameters dry matter, nitrogen and phosphorus.-There was a linear effect of the number of plants on the accumulation of dry matter and phosphorus and quadratic effect on nitrogen accumulation in roots of lettuce. There is a technical feasibility of integrating the intensive Nile tilapia farming in a closed system of recirculating water in the production of hydroponic lettuce, with nutrients remotion such as nitrogen and phosphorus from the effluents and their incorporation in leaves and roots of lettuce.

Keywords: aquaponics, lettuce, Nile tilapia, water quality

\section{RESUMO}

Avaliou-se a viabilidade do consórcio entre a criação de tilápia do Nilo e alface, em sistema hidropônico, e a eficiência sobre a melhoria da qualidade do efluente. A estrutura experimental foi composta de um módulo de produção de peixes e outro para produção vegetal no sistema hidropônico. No sistema hidropônico, foi utilizada a técnica de produção NFT (Nutrient Film Technique), sendo a solução nutritiva utilizada os efluentes da piscicultura. O delineamento experimental utilizado foi o de blocos ao acaso, com quatro tratamentos e três repetições, considerando cada repetição um ciclo de oito dias de hidroponia. Os tratamentos foram: 20; 40; 60 e 80 plantas, para o primeiro, segundo, terceiro e quarto tratamentos, respectivamente. $\mathrm{O} \mathrm{pH}, \mathrm{a}$ condutividade elétrica, a temperatura e o oxigênio dissolvido não se alteraram $(\mathrm{P}>0,05)$ em relação ao efluente de entrada e não foram afetados $(\mathrm{P}>0,05)$ pelo número de plantas. Observou-se 
efeito linear do número de plantas sobre os parâmetros nitrito e ortofosfato, ou seja, quanto maior o número de plantas maior a remoção desses parâmetros na água. A porcentagem de nitrogênio nas folhas e raízes da alface não foi influenciada pelo número de plantas. Houve efeito linear do número de plantas utilizadas sobre o acúmulo nas folhas de alface dos parâmetros matéria seca, nitrogênio e fósforo. Observou-se efeito linear do número de plantas utilizadas sobre o acúmulo de matéria seca e fósforo e efeito quadrático sobre o acúmulo de nitrogênio nas raízes de alface. Existe a viabilidade técnica de integrar a produção intensiva de tilápias em sistema fechado de recirculação de água com a produção de alfaces em hidroponia, ocorrendo a retirada de nutrientes como nitrogênio e fósforo dos efluentes e a incorporação destes nas folhas e raízes da alface.

Palavras-chave: alface, aquaponia, tilápia do Nilo, qualidade de água

\section{INTRODUCTION}

The rapid growth of aquaculture in Brazil in the last years and the potential for expansion has put to the sector has put some issues associated with sustainability and competitiveness. Because of this expansion, the environmental impact of effluent from aquaculture is seen as one of the major environmental problems found in aquatic ecosystems. Considering these aspects, is important conduct studies which establish production systems that reduce the risk of environmental degradation and promote social inclusion (RIBEIRO et al., 2007).

Eler \& Milani (2007) stated that with the evolution of environmental issues and the conditions that the planet presents the rational production of aquatic organisms is an emerging economic activity competing for water resources. Currently, aquaculture faces the challenge of shaping itself to the concept of sustainability, which involves adding new values to the production of knowledge and industry practice.

The term aquaponics is used to conceptualize and identify the production system that promotes the integration of fish farming with hydroponics because these two activities require the application of highly intensive modern technology (SANTOS, 2007).

As reported by Castellani et al. (2009), there is the possibility of an association between intensive fish farming and the cultivation of plants in hydroponics. This integration aims the utilization by the plants of waste (faeces and feed leftovers) dissolved in wastewater, thus achieving an improvement in water quality. The establishment of a clear link between the various water uses and its quality requirements are of fundamental importance.

In systems in which is used intermittent movement, these residues are found in the effluent, which is generally arranged in the receiving body without any treatment and, to minimize the impact of these effluents of fish ponds, it is necessary to use treatment methods or even to reuse this effluent in the irrigation of various crops (CHAVES \& SILVA, 2006).

Thus, the objective of this work was to evaluate the feasibility of growing lettuce (Lactuca sativa L. cv. Americana) intercropped with Nile tilapia (Oreochromis niloticus) in a hydroponics system as well as to evaluate the efficiency of withdrawing nutrients from waste water by lettuce.

\section{MATERIAL AND METHODS}

The experiment was conducted in Centro de Estudos Bioclimáticos 
(CEBIO) at Universidade Estadual do Sudoeste da Bahia (UESB), Campus Itapetinga, BA (09'07'15'S and $\left.40^{\circ} 15^{\prime} 32^{\prime \prime} \mathrm{W}\right)$.
The experimental structure was composed of fish production and other for the plant production in the hydroponic system (Figure 1).

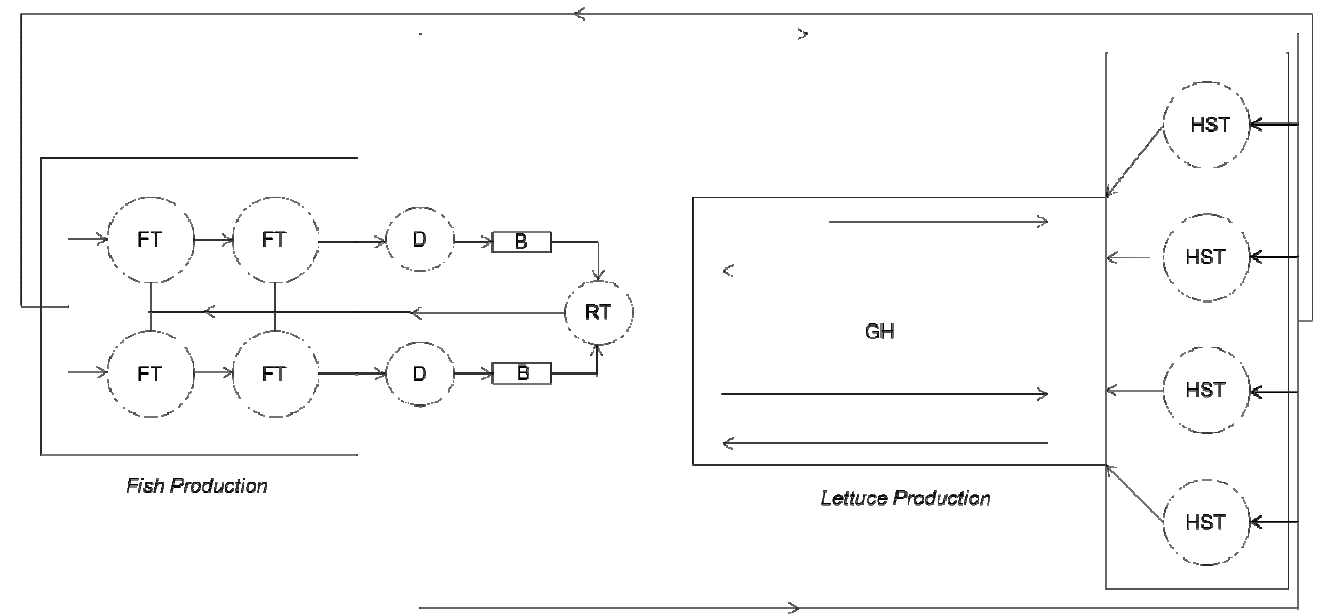

Figure 1. The experimental structure. Arrows represent the flow of water in the integrated system fish-lettuce. FT - Fish tank; D - Decanter; B - Biological filter; RT - Receiver tank; GH - Greenhouse hydroponic; HST - Hydroponic solution tank

The module for fish production contained four glassfiber tanks (1000-L) with conical bottom, in a recirculation water system and under artificial aeration. Connected to the tanks for fish rising, two 400-L conical-shape decanters were placed with the aim of promoting concentration and subsequent solid waste decanting. After the decanter were placed filters (fiberglass tanks of 225-L containing rubble and pillows with oysters shells) which promoted the physical and biological filtration of the wastewater tanks fish production. At the end of this module were used a receiver tank (fiberglass 310-L) from which the effluent was pumped into the tanks of fish production.

The hydroponic system was constructed under a hydroponic greenhouse $(3.0 \mathrm{~m}$ wide, $8.0 \mathrm{~m}$ long and $4.0 \mathrm{~m}$ in height) and inside it, four production benches were placed at two different levels, and in each level, there were two banks in parallel. Each bench was fitted with four PVC gutters with $10 \mathrm{~cm}$ wide, $7.5 \mathrm{~m}$ in length, spaced by $25 \mathrm{~cm}$ from each other, following the longitudinal slope of $2 \%$ and with 29 holes spaced at $20 \mathrm{~cm}$. Thus, it was defined the spacing of the crop with $25 \mathrm{~cm}$ between cultivation row sand $20 \mathrm{~cm}$ between plants.

In the hydroponic system, it was used NFT (Nutrient Film Technique) production technique, in which the nutrient solution passes through the plant root system. In this work, the nutrient solution was the own effluent from the fish rearing tanks.

The circulation of the solution was done by a set of pumps connected to a timer, which kept it on in 15-minute intervals during the day and 30 minutes during the night, alternating periods of feeding and aeration of the roots of their 
accomplishments of their vital functions. Each pump was connected individually to a tank (1000-L), so there was no mixing among treatment effluents.

The fish species used was Nile tilapia (Oreochromis niloticus) with initial weight of $101.5 \pm 2.9 \mathrm{~g}$, maintained a stocking density of $100 \mathrm{fish} / \mathrm{m}^{3}$. Daily the water quality parameters were measured. Dissolved oxygen, temperature, conductivity and $\mathrm{pH}$ were measured using multiparameter devices (YSI model 5512FT e YSI model 63-10FT). The fish were fed daily, ad libitum, in four parcels with commercial extruded feed containing $28 \%$ crude protein (min.) $6 \%$ ether extract (min.) 10\% crude fiber (max.) 8\% moisture content (max.), 9\% mineral matter (max.) 3\% calcium (max.) and 1\% phosphorus (min.). At the beginning and end of the experiment all fish were weighed. Were evaluated weight gain (final weight - initial weight), feed intake, feed conversion ratio (feed intake / weight gain) and survival [(number of dead animals / total number of animals) x 100].

The lettuce (Lactuca sativa L. cv. Americana) was from conventional hydroponic cultivation, with 30 days of production. During the experiment, tilapias were initially kept in the tanks so that there was an accumulation of nutrients in the decanter tank, mainly nitrogen and phosphorus, for the production of the nutrient solution. From the decanter, the effluent was transferred to the hydroponic tanks, by gravity and PVC pipes. This same process was performed twice more, featuring the three repetitions. The experimental design was randomized blocks with four treatments and three replications, each replication was an 8day cycle of hydroponics.

The treatments evaluated were: $5 ; 10$; 15 and 20 plants per gutter, respectively, for the first, second, third and fourth treatments, totaling 20;40, 60 and 80 plants, respectively. The experimental unit was formed by a set of four gutters with the quantity of lettuce plants corresponding to each treatment.

It was analyzed in situ, before and after hydroponic, dissolved oxygen with the aid of an oximeter (YSI model 5512FT), hydrogen potential $(\mathrm{pH})$, electrical conductivity and temperature by using a multiparameter (YSI model 63-10FT).

To assess the levels and removal of nutrients, ammonia nitrogen $\left(\mathrm{NH}_{3}\right)$, nitrite $\left(\mathrm{NO}_{2}^{-}\right)$and orthophosphate $\left(\mathrm{PO}_{4}{ }^{3-}\right)$, at the beginning and on the eighth day of each cycle, 1-L of water from each cistern was collected before and after passage through the hydroponic system. These analyses were performed by using spectrophotometer (HANNA HI83203).

In relation to the leaves and roots of lettuce, the traits evaluated were: percentage of nitrogen, dry matter accumulation, nitrogen and phosphorus. Thus, five plants from each repetition were collected, including five at the beginning of the cycle. After plant harvesting (eight days per cycle), roots and leaves were separated and was hed in distilled water. In the Laboratory of Nutrition and Fish Feeding at the State University of Santa Cruz (UESC), leaves and roots were placed in a ventilated oven at $55^{\circ} \mathrm{C}$ for 72 hours. After that, it was done the grind in a knife mill, by using a 1-mm mesh sieve and the samples were put in flasks sealed for chemical analyses.

In the Laboratory of Animal Nutrition at UESC, analyses of dry matter and nitrogen were made where as phosphorus content was quantified in Laboratory of Vegetal Physiology at Executive Commission for Cocoa 
Farming (CEPLAC). All laboratory analyses followed the methodology described by Silva \& Queiroz (2002).

For comparison between treatments, the average data of physical and chemical parameters of the effluent before and after passing through the hydroponic system, values of the nitrogen and phosphate compounds of the effluent before and after passage through hydroponic system, accumulation of dry matter and nutrients, in lettuce leaves and roots after eight days in hydroponics cultivation were submitted to analysis of variance at 5\% significance level and regression analysis by using the Statistical Analysis System 9.1. (SAS Institute, 2002).

\section{RESULTS AND DISCUSSION}

The water quality parameters in the tanks of fish production monitored during the experimental period, respectively for dissolved oxygen, temperature, conductivity and $\mathrm{pH}$ were $\quad 3.6 \pm 0.23 \mathrm{mg} / \mathrm{L}, \quad 27.7 \pm 0.75^{\circ} \mathrm{C}$, $486 \pm 61 \mu \mathrm{S} / \mathrm{cm}$ e $7.8 \pm 0.4$, remaining within the acceptable range for growing fish (LITTLE \& HULATA, 2000).

Regarding the performance of the fish was observed on average (four tanks), weight gain, feed intake, feed conversion ratio and survival, respectively $1.69 \mathrm{~g} / \mathrm{dia}$, $2.74 \mathrm{~g} / \mathrm{dia}, 1.62: 1$ e $100 \%$, results similar to those obtained by Boscolo et al. (2001) for the same species of tilapia with an initial weight of approximately $70 \mathrm{~g}$ and grown in environmental and nutritional quality of the diet similar.

After effluent had passed through the hydroponic system, it was observed that the $\mathrm{pH}$, electrical conductivity, temperature and dissolved oxygen did not change $(\mathrm{P}>0.05)$ in relation to the effluent input, and was not affected $(\mathrm{P}>0.05)$ by the number of lettuce (Table 1).

Table 1. Values and standard deviations of physical and chemical parameters of the effluent before and after passing through the hydroponic system

\begin{tabular}{lcccccc}
\hline \multirow{2}{*}{ Variable $^{1}$} & & \multicolumn{4}{c}{ Treatment } & \multirow{2}{*}{$\mathrm{F}$} \\
\cline { 3 - 6 } & Input & 20 & 40 & 60 & 80 & \\
\hline $\mathrm{pH}$ & $7.83 \pm 0.46$ & $8.11 \pm 0.34$ & $7.91 \pm 0.61$ & $7.99 \pm 0.58$ & $7.89 \pm 0.27$ & 2,02 \\
$\mathrm{EC}(\mu \mathrm{S} / \mathrm{cm})$ & $502.45 \pm 65.59$ & $552.17 \pm 85.34$ & $567.67 \pm 59.72$ & $511.83 \pm 60.61$ & $547.83 \pm 34.74$ & 3,64 \\
$\mathrm{~T}\left({ }^{\circ} \mathrm{C}\right)$ & $27.6 \pm 0.75$ & $26.8 \pm 1.10$ & $28.3 \pm 1.70$ & $29.0 \pm 1.40$ & $27.7 \pm 0.70$ & 2,01 \\
$\mathrm{DO}(\mathrm{mg} / \mathrm{L})$ & $3.63 \pm 0.28$ & $3.62 \pm 0.62$ & $3.37 \pm 0.61$ & $3.23 \pm 0.55$ & $3.61 \pm 0.42$ & 1,65 \\
\hline${ }_{\mathrm{l}}^{\mathrm{pH}}=$ hydrogen potential; EC $=$ electrical conductivity; $\mathrm{T}=$ temperature; DO = dissolved oxygen.
\end{tabular}

The $\mathrm{pH}$ value near neutrality favors the absorption of most nutrients by the roots inasmuch as the $\mathrm{pH}$ of nutrient solutions affects the availability of mineral nutrients, affecting their absorption by plants.

For electrical conductivity, Martins et al. (2007), found in a work on the phytoremediation of effluents in fish ponds in the basin of the Iraí-Paraná, values in the range of $330 \mu \mathrm{S} / \mathrm{cm}$. The high record of electrical conductivity responds to the high concentrations of nutrients dissolved in the effluent as a function of metabolic waste of tilapia and possible feed leftovers during the productive period. Because there was a concern in avoiding sunlight incidence so that nutrients are not immobilized in algae and phytoplankton, they remained 
dissolved in the water body and were detected by conductivity meter. Similarly, there was no increase in temperature, which did not reduce the solubility of dissolved oxygen, which also remained unchanged.

The ammonia nitrogen after passing through the hydroponic system showed similar behavior between treatments, no statistical difference $(\mathrm{P}>0.05)$ with the increase in the number of heads of lettuce. There was a reduction of 37.36 ; 40.23 ; 48.28 and $44.25 \%$ respectively for the treatments with $20 ; 40 ; 60$ and 80 plants, the levels of ammonia nitrogen in the effluent after passing through the hydroponic system (Table 2).

Table 2. Values and standard deviations of the nitrogen and phosphate compounds of the effluent before and after passage through hydroponic system

\begin{tabular}{|c|c|c|c|c|c|c|}
\hline \multirow{2}{*}{ Variable $^{1}$} & \multirow{2}{*}{ Input } & \multicolumn{4}{|c|}{ Treatment } & \multirow{2}{*}{$\mathrm{F}$} \\
\hline & & 20 & 40 & 60 & 80 & \\
\hline $\mathrm{AN}(\mathrm{mg} / \mathrm{L})$ & $1.74 \pm 0.51$ & $1.09 \pm 0.17$ & $1.04 \pm 0.04$ & $0.91 \pm 0.06$ & $0.97 \pm 0.05$ & 4,18 \\
\hline $\mathrm{NI}^{2}(\mathrm{mg} / \mathrm{L})$ & $15.00 \pm 2.17$ & $6.33 \pm 3.06$ & $2.00 \pm 1.00$ & $0.00 \pm 0.00$ & $0.00 \pm 0.00$ & 19.03 \\
\hline $\mathrm{OT}^{3}(\mathrm{MG} / \mathrm{L})$ & $6.70 \pm 0.10$ & $5.60 \pm 0.40$ & $4.93 \pm 0.17$ & $2.43 \pm 0.51$ & $2.83 \pm 0.35$ & 32,18 \\
\hline
\end{tabular}

${ }^{1} \mathrm{AN}=$ ammonia nitrogen; $\mathrm{NI}=$ nitrite; OT $=$ orthophosphate $;{ }^{2}$ Linear effect $(\mathrm{P}<0.0014)(\mathrm{y}=-0,10500 \mathrm{x}+$ 7,$\left.33333 ; \mathrm{r}^{2}=0,8244\right) ;{ }^{3}$ Linear effect $(\mathrm{P}<0.0002)\left(\mathrm{y}=-0,05408 \mathrm{x}+6,65833 ; \mathrm{r}^{2}=0,8062\right)$.

Through regression analysis, we observed a linear effect of the number of plants on the parameters nitrite and orthophosphate. The greater the number of plants promoted a more intense removal of these parameters in water. It was observed a great reduction in the levels of this nutrient, and it was not detected the presence of nitrite after the passage of hydroponic system in the treatments with 60 and 80 plants. In the analysis of orthophosphate treatments with 20 and 40 plants removed orthophosphate by 16.42 and $26.37 \%$, respectively, whereas treatments with 60 and 80 plants removed orthophosphate by 63.69 and $57.72 \%$, respectively.

According to Lin et al. (2005), the predominance of ammonia nitrogen and phosphorus in the form of orthophosphate in the effluent, in relation to organic forms, facilitates absorption of these nutrients by the plants because when they are in the structures of organic compounds, biological processes will be required to provide these nutrients to plants.

Henry-Silva \& Camargo (2008) and Ramos et al. (2008), evaluating the treatment of effluent from shrimp farming by different species of aquatic macrophytes and macroalgae, respectively, noted improvement in effluent quality in relation to the concentration of ammonia nitrogen, nitrite and phosphate.

For the percentage of nitrogen remotion, all treatments were statistically equal, and these values were very close to those found by Santos (2007), who also worked with aquaponics system using as a nutrient solution, only waste water, from 25 days after transplantation.

Although lettuce absorb relatively small amounts of nutrients compared to other crops, it can be considered a nutrientdemanding species, especially in the final phase of the cycle (KATAYAMA, 1993) similarly to the lettuce used in this experiment. 
It was observed that the hydroponic system was effective in removing nutrients from the effluent evaluated, in addition, it was not changed the physical and chemical characteristics of water, therefore, it can be reused in aquaculture activities, or even thrown in to the water body receiver, reducing the impacts related to eutrophication.

There is still that it is possible to establish a partnership between the establishment of Nile tilapia and lettuce in hydroponic system, keeping the ratio of at least 60 heads of lettuce in the final third of development to depurate 1000-L of effluent.

Regarding the analysis of lettuce leaves, there was no statistical difference $(\mathrm{P}>0.05)$ for the percentage of nitrogen found in leaves, regardless of the amount of plants, resulting in a mean of $4.10 \%$ (Table 3 ).

Table 3. Accumulation of dry matter and nutrients, in lettuce leaves after eight days in hydroponics cultivation

\begin{tabular}{lccccc}
\hline \multirow{2}{*}{ Variable $^{1}$} & \multicolumn{4}{c}{ Treatment } & \multirow{2}{*}{$\mathrm{F}$} \\
\cline { 2 - 5 } & 20 & 40 & 60 & 80 & 0.72 \\
\hline Nitrogen $(\%)$ & $4.21 \pm 0.43$ & $3.89 \pm 0.09$ & $4.07 \pm 0.39$ & $4.15 \pm 0.03$ & 20,75 \\
Dry matter $^{2}(\mathrm{~g})$ & $63.15 \pm 15.75$ & $144.99 \pm 47.53$ & $175.66 \pm 29.47$ & $218.67 \pm 68.50$ & 34,13 \\
Nitrogen $^{3}(\mathrm{~g})$ & $2.76 \pm 0.78$ & $5.43 \pm 1.24$ & $6.33 \pm 1.86$ & $8.81 \pm 1.24$ & 30,52 \\
Phosphorus $^{4}(\mathrm{mg})$ & $439.75 \pm 68.67$ & $1000.01 \pm 181.88$ & $1064.64 \pm 247.78$ & $1600.04 \pm 373.39$ & $30,953) ;$ \\
${ }^{\mathrm{T}}$ Values expressed on dry matter basis; ${ }^{2}$ Linear effect $(\mathrm{P}<0.0010)\left(\mathrm{y}=2,48622 \mathrm{x}+26,30540 ; \mathrm{r}^{2}=0,9553\right)$ & \\
${ }^{3}$ Linear effect $(\mathrm{P}<0.0002)\left(\mathrm{y}=0,09533 \mathrm{x}+1,06728 ; \mathrm{r}^{2}=0,9698\right) ;{ }^{4}$ Linear effect $(\mathrm{P}<0.0003)(\mathrm{y}=17,72746 \mathrm{x}$ \\
$\left.+139,73789 ; \mathrm{r}^{2}=0,9306\right)$.
\end{tabular}

Similarly, Baumgartner et al. (2005) found no significant differences for percentage of nitrogen in leaves, using different sources of wastewater from agro-industrial activities in the irrigation of lettuce.

There was a linear effect of the number of plants on the accumulation in lettuce leaves parameters dry matter, nitrogen and phosphorus. By analyzing means of dry matter incorporated into lettuce leaves, the increase was $246 \%$ higher when using 80 plants compared to treatment consisting of 20 plants. In this experiment, it was observed an average growth of $0.39 \mathrm{~g} / \mathrm{plant} /$ day of dry matter. Martins et al. (2009) observed maximum dry matter accumulation of $5.68 \mathrm{~g} /$ plant, when they evaluated the curve of absorption of nutrients in Isabela lettuce cultivar, in hydroponic at the conditions in Natal, RN, Brazil.
Beninni et al. (2005), assessing the growth of Veronica cultivar, observed in the last week of cultivation, in the traditional system and hydroponic cultivation, dry matter growth of 0.42 and $0.49 \mathrm{~g} / \mathrm{plant} / \mathrm{day}$, respectively.

In this experiment, the average accumulation of nitrogen in lettuce leaves was $0.02 \mathrm{~g} / \mathrm{plant} / \mathrm{day}$. Similarly, Grangeiro et al. (2006) observed, for different lettuce cultivars grown in traditional cultivation, in the highest accumulation phase, an increase of $0.03 ; 0.02$ and $0.02 \mathrm{~g} / \mathrm{plant} /$ day for the cultivars Babá de Verão, Tainá and Verônica, respectively.

Regarding phosphorus incorporation in leaves of lettuce it was observed in this experiment accumulation at an average of $2.65 \mathrm{mg} / \mathrm{plant} /$ day of phosphorus. Lower value was obtained by Martins et al. (2009), who observed phosphorus 
accumulation in hydroponic lettuce cultivar Isabela of $1.06 \mathrm{mg} / \mathrm{plant} /$ day. Similar value was obtained by Faquin et al. (1996), with accumulation of phosphorus of $2.36 \mathrm{mg} /$ plant/day in hydroponic lettuce cultivar Verônica. However, in the traditional system of cultivation, Grangeiro et al. (2006) observed the accumulation of phosphorus exceeding 5.67; 3.67 and $3.67 \mathrm{mg} / \mathrm{plant} /$ day for the cultivars Babá de Verão, Verônica and Tainá, respectively.

The amount of dry matter produced at the end of the cycle directly influenced the outcome of nitrogen and phosphorus removed from waste water and later incorporated in the leaves of lettuce, as well as the accumulation of nutrients is directly related to the accumulation of dry matter in lettuce plants, both hydroponic and conventional systems.

The differences observed in this experiment might be related to the growing season, the cultivar chosen, the time from cultivation to harvest and the type of cultivation (LOPES et al., 2003; MARTINS et al., 2009). The use of cultivars poorly adapted to low temperatures and high luminosities may result in low productivity (QUEIROGA et al., 2001).

Regardless of the quantity of plants, the percentage of nitrogen after the eight days has remained unchanged $(\mathrm{P}>0.05)$ with an average of $4.44 \%$, and this nutrient is distributed proportionally between leaves and roots (Table 4).

Table 4. Accumulation of dry matter and nutrients in roots of lettuce after eight days in hydroponics cultivation

\begin{tabular}{lccccc}
\hline \multirow{2}{*}{ Variable $^{1}$} & \multicolumn{4}{c}{ Treatment } & \multirow{2}{*}{$\mathrm{F}$} \\
\cline { 2 - 5 } & 20 & 40 & 60 & 80 & \\
\hline Nitrogen $(\%)$ & $4.66 \pm 0.11$ & $4.37 \pm 0.24$ & $4.37 \pm 0.26$ & $4.34 \pm 0.16$ & 2,47 \\
Dry matter $^{2}(\mathrm{~g})$ & $16.29 \pm 2.31$ & $38.97 \pm 4.83$ & $50.14 \pm 1.31$ & $60.93 \pm 12.59$ & 62,85 \\
Nitrogen $^{3}(\mathrm{~g})$ & $0.79 \pm 0.08$ & $1.41 \pm 0.54$ & $2.10 \pm 0.34$ & $1.93 \pm 0.27$ & 13,16 \\
Phosphorus $^{4}(\mathrm{mg})$ & $139.11 \pm 25.87$ & $378.15 \pm 105.44$ & $588.33 \pm 93.13$ & $622.63 \pm 172.68$ & 30,59 \\
\hline
\end{tabular}

${ }^{\mathrm{T}}$ Values expressed on dry matter basis; ${ }^{2}$ Linear effect $(\mathrm{P}<0.0001)\left(\mathrm{y}=0,72543 \mathrm{x}+5,30859 ; \mathrm{r}^{2}=0,9620\right)$;

${ }^{3}$ Quadratic effect $(\mathrm{P}<0.0021)\left(\mathrm{y}=-0,00049564 \mathrm{x}^{2}+0,07021 \mathrm{x}-0,46620 ; \mathrm{R}^{2}=0,9586\right) ;{ }^{4}$ Linear effect $(\mathrm{P}<0.0003)\left(\mathrm{y}=8,30358 \mathrm{x}+16,87767 ; \mathrm{r}^{2}=0,9226\right)$.

There was a linear effect of the number of plants on the accumulation of dry matter and phosphorus in roots of lettuce. The average value of dry matter incorporated by the roots was $0.10 \mathrm{~g} / \mathrm{plant} /$ day. Beninni et al. (2005), assessing the growth of the cultivar Verônica in hydroponics, observed in the last week of cultivation, increase in dry matter weight of $0.08 \mathrm{~g} / \mathrm{plant} / \mathrm{day}$. Compared to nitrogen accumulation in lettuce roots, quadratic effect was observed in the number of plants on this parameter. The maximum accumulation of nitrogen in the lettuce roots were obtained from 71 plants (Table 4 and Figure 2).

Cortez et al. (2009), with the objective of evaluating the association of hydroponic lettuce cultivation with utilization of residues from intensive breeding system of fish at 56 days of age, considering that the transplant occurred at 21 days after sowing, found values for nitrogen removal rate below those observed in this work, which may be related to the fact that the lettuce used are from different varieties. 
However, for the values of phosphorus incorporated by the lettuce leaves were compatible to that found in this experiment and this can be explained due to high phosphorus availability in the two solutions, since they are derived from intensive aquaculture.

Hydroponic lettuce cultivation associated with fish farming has the same yield and quality of conventional hydroponic lettuce. However, in most studies it is observed that the fish are able to supply sufficient quantities of almost all plant nutrients except potassium and magnesium, which makes it necessary to correct mineral supplementation for the correct development of plants (CORTEZ et al., 2009; QUILLERÉ et al., 1995).

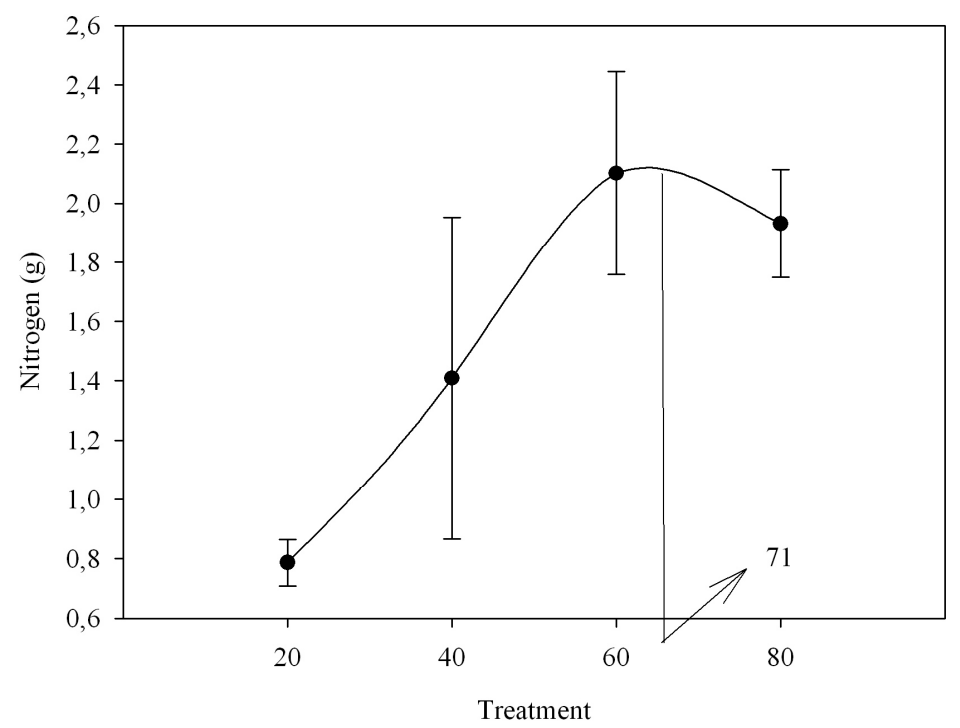

Figure 2. Effect of the number of plants on nitrogen accumulation in lettuce roots

It is highlighted that the plants were in the final terms of production, and ready for marketing and consumption, which means that the nutrient solution can be replaced in the final stage of the lettuce production by effluent from fish farming. This indicates the technical feasibility of aquaponics, with the possibility of offering two products for marketing.

There is a technical feasibility of integrating the intensive farming of tilapia in a closed system of recirculating water with the production of hydroponic lettuce. There is a phytodepuration of effluents from fish farming through the removal of nutrients such as nitrogen and phosphorus from waste water and their incorporation in leaf and root tissues of lettuce. The increase in the number of lettuce plants in contact with the effluent promotes greater incorporation of nutrients in plant tissues.

\section{ACKNOWLEDGEMENTS}

The authors would like to express their sincere thanks to $\mathrm{CNPq}$ (Brazilian Research Council) and CAPES (Coordination for the Improvement of Higher Level Personnel) for the financing of the research project. 
Rev. Bras. Saúde Prod. Anim., Salvador, v.14, n.2, p.371-381 abr.jun., 2013 http://www.rbspa.ufba.br ISSN 15199940

\section{REFERENCES}

BAUMGARTNER, D.; SAMPAIO, S.C.; SILVA, T.R.; TEO, C.R.P.A.; GOMES, B.M. Alface irrigada com águas residuárias de atividades agroindustriais.

Acta Scientiarum. Agronomy, v.27, n.4, p.697-705, 2005.

BENINI, E.R.Y.; TAKAHASHI, H.W.; NEVES, C.S.V. Concentração e acúmulo de macronutrientes em alface cultivada em sistemas hidropônico e convencional. Semina: Ciências Agrárias, v.26, n.3, p.273-282, 2005.

BOSCOLO, W.R.; HAYASHI, C.; SOARES, C.M.; FURUYA, W.M.; MEURER, F. Desempenho e características de carcaça de machos revertidos de tilápias do Nilo

(Oreochromis niloticus), linhagens tailandesa e comum, nas fases inicial e de crescimento. Revista Brasileira de Zootecnia, v.30, n.5, p.1391-1396, 2001.

CASTELLANI, D.; ABIMORAD, E.G.; CAMARGO, A.F.M. Aquaponia: aproveitamento do efluente do berçário secundário do camarão-da-amazônia (Macrobrachium amazônicum) para produção de alface (Lactuca sativa) e agrião (Rorippanasturtium aquaticum) hidropônicos. Bioikos, v.23, n.2, p.65-75, 2009.

CHAVES, S.W.P.; SILVA, I.J.O.

Integração da piscicultura com a agricultura irrigada. Thesis, v.6, n.1, p.917, 2006.

CORTEZ, G.E.P.; ARAÚJO, J.A.C.; BELLINGIERI, P.A.; DALRI, A.B. Qualidade química da água residual da criação de peixes para cultivo de alface em hidroponia. Revista Brasileira de Engenharia Agrícola e Ambiental, v.13, n.4, p.494-498,2009.
ELER, M.N.; MILLANI, T.J. Métodos de estudos de sustentabilidade aplicados a aquicultura. Revista Brasileira de Zootecnia, v.36, p.33-44, 2007. Supl.

FAQUIN, V.; FURTINI NETO, A.E.; VILELA, L.A.A. Produção de alface em hidroponia. Lavras: Universidade Federal de Lavras, 1996. 50p.

GRANGEIRO L.C.; COSTA, K.R.; MEDEIROS, M.A.; SALVIANO, A.M.; NEGREIROS, M.Z.; NETO, F.B.; OLIVEIRA, S.L. Acúmulo de nutrientes por três cultivares de alface cultivadas em condições do SemiÁrido. Horticultura Brasileira, v.24, n.2, p. 190-194, 2006.

HENRY-SILVA, G.G.; CAMARGO, A.F.M. Tratamento de efluentes de carcinicultura por macrófitas aquáticas flutuantes. Revista Brasileira de Zootecnia, v.37, n.2, p.181-188,2008.

KATAYAMA, M. Nutrição e adubação de alface, chicória e almeirão. In. FERREIRA, M.C. (Ed.). Nutrição e adubação de hortaliças. Piracicaba: Potafós, 1993. p.141-148.

LIN, Y.; JING, S.R.; LEE, D.Y.; CHANG, Y.F.; CHEN, Y.M.; SHIH, K.C. Performance of a constructed wetland treating intensive shrimp aquaculture wastewater under high hydraulic loading rate. Environmental Pollution, v.134, n.1, p.411-421, 2005.

LITTLE, D.C.; HULATA, G. Strategies for tilapia seed production. In: BEVERIDGE, M.C.M.; McANDREW, B.J. (Eds). Tilapias: biology and exploitation. Fish and fisheries series. The Netherlands: Kluwer, Academic Publishers, 2000. p.267-326. 
LOPES, M.C.; FREIER, M.; MATTE, J.M.; GARTNER, M.; FRANZENER, G.; CASIMIRO, E.L.N.; SEVIGNAMI, A. Acúmulo de nutrientes de alface em cultivo hidropônico no inverno.

Horticultura Brasileira, v.21, n.2, p.211-215, 2003.

MARTINS, A.P.L.; REISSMANN, C.B.; FAVARETTO, N.; BOEGER, M.R.T.; OLIVEIRA, E.B. Capacidade da Typha dominguensis na fitorremediação de efluentes de tanques de piscicultura na Bacia do Iraí -

Paraná. Revista Brasileira de

Engenharia Agrícola e Ambiental, v.11, n.3, p.324-330, 2007.

MARTINS, C.M.; MEDEIROS, J.F.; LOPES, W.A.R.; BRAGA, D.F.;

AMORIOM, L.B. Curva de absorção de nutrientes em alface hidropônica.

Revista Caatinga, v.22, n.4, p.123-128, 2009.

QUEIROGA, R.C.F.; BEZERRA

NETO, F.; NEGREIROS, M.Z.;

OLIVEIRA, A.P.; AZEVEDO,

C.M.S.B. Produção de alface em função de cultivares e tipos de tela de sombreamento nas condições de

Mossoró. Horticultura Brasileira, v.19, n.3, p.192-196, 2001.

QUILLERÉ, I.; ROUX, L.; MARIE, D.; ROUX, Y.; GOSSE, F.; MOROT-

GAUDRY, J.F. An artificial productive ecosystem based on a fish/bacteria/plant association. 2. Performance.

Agriculture, Ecosystems and

Environment, v.53, n.1, p.19-30, 1995.
RAMOS, R.; VINATEA, L.;

ANDREATTA, E.R.; COSTA, R.H.R. Tratamento de efluentes de tanques de criação de Litopenaeus vannamei por sedimentação e absorção de nutrientes pela macroalga Ulva fasciata. Boletim do Instituto de Pesca, v.34, n.3, p.345353,2008 .

RIBEIRO, K.S.; FERREIRA, E.; COSTA, M.S.S.M.; GAZOLLA, D.; SZIMANSKI, C. Uso de biofertilizante no cultivo de alface hidropônica.

Revista Brasileira de Agroecologia, v.2, n.2, p.1600-1603, 2007.

SANTOS, O.S. Aquaponia:

Associação da Criação de Peixes com a produção Hidropônica de Plantas.

Santa Maria, RS: Universidade Federal de Santa Maria, 2007. (Informe Técnico, 6).

SAS Institute. Statistical analysis system: user's guide: statistics. Version 9.1. 4.ed. Cary. NC., 2002.

SILVA, D.J.; QUEIROZ, A.C. Análise de alimentos: métodos químicos e biológicos. 3.ed. Viçosa: Universidade Federal de Viçosa, 2002. 235p.

Data de recebimento: 19/03/2013

Data de aprovação: 25/06/2013 